\title{
HRM and Employee Significant Behavior: Explaining the Black Box through AMO Theory
}

\author{
Nik Hazimah Nik Mat*, Wan Norhayati Mohamed, Hayatul Safrah Salleh and \\ Yusnita Yusof
}

Faculty of Business, Economics and Social Development, Universiti Malaysia Terengganu, Malaysia, 21030 Kuala Terengganu, Terengganu, Malaysia

\begin{abstract}
The purpose of this study is to explore the employees' perceptions towards the role of HRM policies and practices in assisting them to perform the desired behavior in contributing to the organizational goals achievement. Employees' perceptions are explored through their actual experiences with the implementation of HRM policies and practices. Interviews were conducted with employees in five different star-rating hotels to understand contextual factors that can be observed. Different perceptions on the role of HRM policies and practices in influencing employees' performance are reported from the interviews. Instead of acting as a medium to transmit the message of their work expectations, employees view the HRM policies and practices as a common process happening in their organization and unrelated to their work demand. Therefore, findings of this study could light a torch of awareness for organizations to give more attention to the employees' responses and feedback to minimize their dysfunctional behaviors that are detrimental to organizational achievement. Suggestions are given to increase the employee desired behavior relevant to the organizations from the perspective of AMO theory.
\end{abstract}

Keywords: AMO theory, behavior, employee performance, hotel, human resource management, job expectations

ARTICLE INFO

Article history:

Received: 12 May 2021

Accepted: 20 October 2021

Published: 08 December 2021

DOI: https://doi.org/10.47836/pjssh.29.4.26

E-mail addresses:

nikhazimah@umt.edu.my (Nik Hazimah Nik Mat)

wannor@umt.edu.my (Wan Norhayati Mohamed)

hayatul@umt.edu.my (Hayatul Safrah Salleh)

yusnitayusof@umt.edu.my (Yusnita Yusof)

* Corresponding author

\section{INTRODUCTION}

Human Resource Management (HRM) has been recognized as an essential tool for organizations to manage their operations while adapting to the challenges of a complex business environment. Much effort is tailored to explain the relationship between HRM and performance. Researchers believed 
that employee performance is valuable to assist the organization in gaining a competitive advantage as they are expected to play their roles accordingly in any situation. Therefore, the purpose of HRM is crucial as it enables the organization to influence employee behavior to achieve organizational goals (Purcell \& Hutchinson, 2007). HRM offers a list of workplace processes through its policies ranging from recruitment, performance management, training, rewards, and benefit until the end of the employment contract (Baran et al., 2002). Organizations have used these policies to manage their employees, regardless of size and industry.

However, the effectiveness of the HRM policies and practices is still an ongoing issue debated by researchers because of the gap between intended and actual employee performance, which remains familiar to most organizations (Khilji \& Wang, 2006). More attention is demanded on the implementation aspect because the effectiveness of HRM policies and practices could only be proven when it is executed successfully by managers (Nehles et al., 2006). It ensures the primary purpose of sending the right message to the employees on their work role expectations can be accomplished through those policies. Instead of providing a descriptive explanation on any issue at the workplace, researchers urged for more holistic research on the HRM study to explore details about the underlying causes and factors that may influence a particular issue. Therefore, the contribution of the research finding is not limited to theoretical development, but more importantly, to increase its ability to be put into action (Syed et al., 2009).

While employees' performance is a critical issue for most organizations, rapid changes in the business environment with high uncertainties have increased the concern of the top management to formulate an effective strategy for their organization. As such, organizations are required to be more flexible in doing their business. It is to increase their ability in adapting to the changes of the market. This situation also requires employees to have the necessary skills in line with the increased expectations of their jobs. However, for the organizational strategy to work well in accomplishing the goals, this requires the top management and employees to be on the same page in understanding the job expectations that likely to change based on the current business situation. It is to ensure that employees' performance can be monitored and improved to meet the employer's expectations. Therefore, the focus of this study is to explore the perceptions of employees towards the role of HRM policies and practices in assisting them in performing and contributing to the organization.

\section{LITERATURE REVIEW}

\section{HRM Policies and Practices}

HRM policies and practices can be used to influence employees' perceptions of the required performance of their roles (Purcell \& Hutchinson, 2007). These can be done through a rich array of 
policies, including selection, training, performance management, motivation, and career planning (Baran et al., 2002; Boxall \& Steenveld, 1999; Delaney \& Huselid, 1996). From the beginning of the employment process, an appropriate recruitment and selection mechanism could ensure that an organization gets a candidate who can perform well and contribute to achieving the organizational goals. Moreover, a comprehensive training program is needed to equip the employees with the desired skills and knowledge to cope with heightened demand for their work expectations. Since employees come from diverse backgrounds and areas of expertise, training and development are essential to equip themselves with appropriate skills and knowledge when they perform their jobs.

Many kinds of research on the importance of HRM practices have explored the relationship between HRM and employee performance (i.e., Bowen \& Ostroff, 2004; Boxall \& Purcell, 2011; Purcell \& Hutchinson, 2007). Their work leads to understanding possible organizational outcomes that arise from the perception of HRM practices among employees. It includes organizational commitment and work engagement (Charlwood, 2015). These positive attitudes can motivate employees to participate and engage in organizational strategy, leading to higher citizenship behavior (Wright, 2003). In addition, more work behaviors that are significant to the organizational outcomes can be achieved when the absenteeism and turnover are decreasing (Fredrickson \& Branigan, 2003).
Purcell and Hutchinson (2007) developed the people management-performance causal chain to explain the relationship between HRM policies and practices to unit-level outcomes. They have proposed that the intended expectations of the management are sent through the development of the HRM policies in the organization. Based on these policies, the HR people will translate it into real action and process at the workplace. Employees will develop their perceptions of the implemented policies through their experiences. As a result, it will influence their attitudes and behavior towards their jobs. Researchers highlighted that the perception of HRM practices plays a significant part that influences employee attitude and behavior (Alfes et al., 2013; Jiang et al., 2017; Mat et al., 2017). Most recent studies found a more reliable connection between employees' perceptions of HRM practices and employee work behavior, as compared to the actual practices executed by managers (Aryee et al., 2012; Den Hartog et al., 2013; Jensen et al., 2013; Kehoe \& Wright, 2013).

The relationship between HRM and performance has long been discussed. For instance, Hall and Torrington (1998) agreed that HRM policies and practices are useful for changing employees' attitudes towards their roles. For employees to understand what they are supposed to do, Hall and Torrington (1998) proposed that the development of procedures and manuals is needed to ensure employees' performances meet the expectations of their superiors. It is especially true in the complex business 
environment where employees must adapt to the current changes that increase their work demand. Only with that capability could employees contribute to the organizational achievement as a source for competitive advantage through HRM policies and practices that influence the employees' work behavior (Delery \& Shaw, 2001).

Debates on the HRM-performance link drive to the issue about what HRM practices and policies do that lead to better performance (Buyens \& De Vos, 2001). Even though many approaches have been developed to accommodate organizational conditions, continuous debates arise as to their subjectivity and difficulty in measurement. Therefore, researchers suggest that combining approaches may produce a better result and give value to HRM. This suggestion shows the importance of gathering the views of HR people closely involved with the implementation of HRM policies and practices. Researchers believed that understanding both parties of employees and superiors are required to determine the appropriateness of HRM policies and practices from different perspectives; policymaker and implementer. However, most studies neglect the employees' perception at the individual level (Jiang et al., 2017; Yuan \& Woodman, 2010). As a result, employees often interpret the HRM policies and practices differ from that of top management (Wright \& Nishii, 2013). Furthermore, the exploration of the implementation of these policies is still under researched (Nehles et al., 2006). This is a crucial gap to be filled because employees' actual performances often fail to reflect what is required by their role evaluators through the message sent by HRM policies and practices in the organization (Purcell \& Hutchinson, 2007; Mat et al., 2017).

In terms of the research gap, many HRM scholars pay significant attention to employee perceptions of HRM practices to improve the HRM-performance relationship (Baluch, 2017; Jiang et al., 2017). Researchers believed that the interpretation of HRM practices from employees' perspectives as the end-users is supposed to receive due consideration to improve HRM effectiveness (Nehles \& Veenendaal, 2017). Other than that, the non-western perspective is found lacking in HRM studies (Jack et al., 2013; Kaufman, 2015; Mayrhofer et al., 2019). More exploration is suggested in other contextual settings to provide a more practical solution to HRM issues by integrating it into the local realities (Cooke, 2017). Researchers suggest that HRM matters should not be assumed to work the same way in different places. Due consideration to be given to conducting HRM research beyond the Western countries. One of the misconceptions in understanding HRM research is the assumption that everything will work the same way regardless of the context (Mayrhofer et al., 2019). Thus, although HRM practices have long been discussed, the evolution of HRM studies requires continuous exploration due to the time changes and context differences for a better management adaptation over time 
(Cooke, 2017). The gap can be bridged through an appropriate methodological setting.

The methodological limitations of HRM studies have long been debated among scholars. Researchers urged for a better approach in narrowing the gap between theoretical findings with practicality due to the inability of the research methodology to explain the observed findings. The findings, drawing upon the qualitative research paradigm, are expected to provide more attention to detail in regards to local realities, which is crucial to bridge the gap of HRM-employees' performance link. Further, considering employees voice to investigate on the effectiveness of HRM practices are crucial in bridging the gap of HRM-performance black box (Budjanovcanin, 2018). Employees' voices can better represent the role holder's opinions on HRM practices than role sender expectations (top management). Thus, the HRM research findings that aim to understand the phenomena in a particular research setting are better conceptualized through a qualitative research methodology that is able to explain 'why' and 'how' it is happening the way it is (Cooke, 2017).

\section{AMO Theory}

Researchers have investigated factors influencing individual performance to understand the challenges of performing the work role (Boxall \& Purcell, 2011). The determinants influencing work performance have been developed using the Ability, Motivation, and Opportunity (AMO) framework (Boxall \& Purcell, 2011). In contrast to other established theories in HRM studies, namely contingency theory and resource-based view, AMO has been used to explore organizational psychology to find the cause of action rather than the effect of HRM performance (Paauwe, 2009). This difference has made some researchers view AMO as an added value of resource-based view (Paauwe \& Boselie, 2005). The AMO components are described as the resources needed by the employees to perform well. Moreover, these elements are interrelated, suggesting the necessity for all components to exist at the workplace (Jiang et al., 2012). Of more significant concern, the advantage of using this framework is explaining the gap in the HRM-performance black box (Harney \& Jordan, 2008). Moreover, the association between HRM policy and practices and performance could justify the reason behind the actual event happening at the workplace.

In discussing an appropriate theory to be used for a study, researchers suggest that powerful theory depends on its ability to provide a detailed explanation about the issue in the chosen context (Child \& Marinova, 2014). In this study, an attempt to explore employees' perceptions about HRM practices that influence their performance is deemed appropriate with the AMO concepts. Furthermore, AMO is used widely by recent HRM studies, especially to explore about HRM-performance link (i.e., BosNehles et al., 2013; Malik \& Lenka, 2019; Nadeem \& Rahat, 2021; Salas et al., 2021). Therefore, AMO is appropriate for this study 
as the main focus is to explore employees' perspectives. In addition, it is in line with the AMO concepts' application to exposing individual-level ability and motivation and system-level opportunities that also apply to assess individual understanding of the practices (Szulc et al., 2021).

Ability. Ability is an essential factor influencing employee behavior and task performance (McShane \& Travaglione, 2007). It encompasses the employees' necessary knowledge, skills, and aptitudes to perform their job (Boxall \& Purcell, 2011). McShane and Travaglione (2007) have grouped these elements as natural aptitudes and learned capabilities. In the former, employees' natural talents can assist them in performing their tasks effectively. In the latter, employees' skills and knowledge can make their behavior and task performances unique. The combination of these elements is known as competencies.

Skills and abilities play an important role in employee performance, mainly related to the higher workload given to the employees due to the changes in the job structure (Cunningham \& Hyman, 1995; Jackson \& Schuler, 1995). Therefore, skill development is essential to solving the issue of the skills gap among employees in the modern workplace (Payne, 2012). Furthermore, it has been proven that to accomplish many positive organizational outcomes; employee skills need to be utilized effectively (Buchanan et al., 2010). To achieve that, the researcher suggested improving the organizational policy so that the skills demand employees required that to meet the organizational expectations could be identified (Payne, 2012). It is important because there is a time constraint to utilizing skills if the management does not recognize them correctly.

Motivation. Researchers point out that skilled employees will not perform well if they are not motivated (Delaney \& Huselid, 1996). In discussing this issue, the form and structure of an organization's HRM system will impact employees' motivational levels in several ways. First, organizations may implement an approach of positive reinforcement to guide employee behavior towards specific organizational goals. It can be done through a merit pay or incentive compensation system that rewards the employees when they successfully achieve the desired goals. Organizations may, however, adopt a negative reinforcement approach such that grievance procedures are used to avoid undesirable behaviors. By doing this, employees are motivated to work harder because they realize the consequences of their work behavior. While most knowledge workers in the modern workplace highly value financial rewards, this could be challenging for the organization to develop a fair and equal policy for all employees (Guest, 2017).

Opportunity to Perform. AMO theory suggests that employees who are given the opportunity to contribute and perform their job will produce more positive organizational outcomes (Boxall \& Purcell, 
2011). Opportunity is described as the engagement in job-related behavior, which can be achieved through job design and involvement (Guerci et al., 2017). A previous study found the relationship between job design and various employees' attitudes at the workplace (De Jong et al., 2015). This is especially true with developing innovative workplace behavior in the modern workplace where employees are required to adapt to the current changes and perform their job accordingly. Besides, assigning employees to work in a team is also viewed as part of the opportunities for employees to perform (Gerhart, 2005). Researchers found that the chance to perform influences employees' motivations in their performances. The concept of opportunity to perform suited the prevalent issue of work engagement to give employees more autonomy to perform their jobs. Importantly, researchers highlighted the importance of enhancing the perception of HRM practices among employees to engage them with innovative behavior that is significant to organizational achievement (Nehles \& Veenendaal, 2017). As such, HRM practices provide some guidelines for employees to behave accordingly and meet their work expectations that rapidly change in line with the changes in their work demand.

\section{Research Context: Malaysian Hotel}

Industry. The hotel industry in Malaysia is extensive, with accommodation ranging from lodging houses to 5-star hotels. The Malaysian Association of Hotels (MAH) was established in 1974 to support government initiatives in enhancing the efficiency of the hotel industry in Malaysia after realizing the increasing demand in the hotel industry. With over 900 members, MAH provides the platform to improve the service quality of Malaysian hotels and supports government initiatives to ensure the growth and development of the service sector as well as the tourism industry. For instance, an annual survey conducted by MAH shows a remarkable contribution of the hotel industry towards the development of the tourism industry in Malaysia with its increased number of tourists' arrivals and the attraction of more foreign investments.

Unfortunately, the survey also revealed uneven performance amongst hotels in Malaysia based on the locations (Horwath HTL, 2011). The major contributor to the growth of the Malaysian hotel industry is hotels in Kuala Lumpur, while the performance of hotels in other cities has declined. The performance of hotels in Kuala Lumpur is consistent, regardless of changing business environments. This location is where most of the luxurious and five-star hotels are located. It is probably another reason that contributes to the higher performance compared to hotels in other places. Instead, lower-rated hotels in Malaysia are yet to contribute to the growth of the Malaysian service industry.

Researchers have noted that a high turnover rate of employees is a significant problem in the Malaysian hotel industry (Abdullah et al., 2010). Three factors are associated with this problem: the employees' relationships with supervisors, 
income, and tenure. As the hotel industry's performance is vital to developing the tourism sector in Malaysia, the problem of employee performance should be further investigated as it could negatively affect the hotel performance that is detrimental to the national agenda.

Having a national context or countrylevel differences (Malaysia as of this study) is a strong fundamental mechanism to explain the current complex HRM issue; however, the same issue has been explored in other parts of the world (Parry et al., 2020).

\section{METHODOLOGY}

This research employed qualitative research methodology to explore the employees' understanding about the implementation of HRM practices in their organizations. Qualitative research design is appropriate for this study as the research aimed to gather the information through the employees' experience and get detailed information on the real situation from the employee's point of view. Further, a qualitative research design is not merely a methodological choice but more towards exploring the emerging HRM issues and ensuring the continuation of investigation about a particular phenomenon to cater to many situations and contexts as of the HRM research gap. Furthermore, qualitative methodology is appropriate to conceptualize findings, especially to integrate many contextual elements with the research data to offer a more practical solution that works well in real life (Cooke, 2017). On the other hand, positivist-oriented research has a limitation in explaining the complexity of a situation, which is significant for formulating management strategy and solution (Jackson et al., 2014; Kaufman, 2015).

A single data source is considered sufficient depending on the purpose of the study (Parry et al., 2020). Thus, hotel employees are chosen as respondents of this study for their position as 'role holders' who interpret the message of HRM practices to perform their work. The selection of employees is appropriate for this study as they are the most knowledgeable source who experienced the actual execution of HRM practices in their hotel. The data collection process was done from August 2016 until December 2016. While the evolution of HRM issues occurs continuously, the data gathered from this study is relevant to observing changes affecting the organizations over time (Edwards et al., 2013). Perhaps, findings of this study can be used to compare the results before and after the pandemic Covid 19 happened, which aimed at exploring the adaptation strategy that may be applicable for the hotel industry in challenging times. The list of hotels is obtained from Malaysian Association Hotels (MAH), where five hotels in the East Coast Peninsular Malaysia have been chosen as a case study. The researcher had asked permission from the management of each hotel before the interview sessions were scheduled. It ensures the quality of the data gathered from the respondents as they were unlikely to be distracted during the interview when the time was set earlier. 
Different star-rated hotels are taken into consideration to observe the impacts of contextual elements on the implementation of HRM policies and practices. This study is exploratory in which an attempt is made to investigate the actual situation happening in all hotels. Every organization defines people management: the qualitative methodology explains the complexity of the issues under contextual circumstances. The interpretation of the respondents to the interview questions determines the validity of the data. Researchers suggest that the appropriate sampling selection depends not only on which organizations are chosen but also on the suitable respondents who have knowledge of the issue being explored (Parry et al., 2020). Data collection is done based on the accessibility of the interviewer to get cooperation from the hotels. Organizations are taken from the service sector primarily based on the sector's importance to the Malaysian economy. The empirical basis of this study consists of 32 interviews with the hotel employees in the hotel's case study. During the interviews, five main HRM policies and practices are asked: recruitment, selection, performance management, rewards and benefits, and training. For each HRM practice, the study analyses how employees understanding of implemented HRM policies influence their work performance. Content analysis has been used to interpret the data from those interviews and determine the theme from the respondents' experiences. The theoretical theory underlying the findings of this study is based on the AMO theory.
The use of AMO theory in this study is acted as a guideline for 'theory building' rather than 'theory testing.' As a theorybuilding mechanism, the findings of this study have not been pre-determined based on AMO assumptions. Instead, it is used to make sense of the information gathered from the respondents (Anderson \& Kragh, 2010). Without an underlying theory, researchers may not integrate their findings into a theoretical stance sensibly, exposing the data with personal biases, especially for novice researchers (Gioia et al., 2013). Further, having an underlying theory does not limit the exploratory nature of the research because new knowledge can be developed by extending and challenging the existing theory to yield novel insights from the current research findings (Epp \& Otnes, 2021).

\section{RESULTS AND DISCUSSION}

Interviews were conducted with hotel employees from various departments. A total of 32 respondents were interviewed to represent five hotels: the number differs based on the accessibility and availability of employees agreed upon by the management of the hotels. The interview sessions were scheduled based on the availability of the respondents to reduce distractions that could negatively influence their feedback to the interview questions. The demographic of respondents is illustrated in Table 1. In terms of the star rating, the researcher was unable to get responses from the 4-star hotels due to the issue of accessibility. Other star rating hotels are represented by one hotel each and 
two hotels for five stars. Based on table 1, most respondents are female, aged between 20 to 40, and have a secondary school certificate. Besides, all respondents work for three different departments: front office, administration, and food and beverages.

\section{HRM Practices}

In general, respondents in all hotels' case studies have shown a limited understanding when asked about 'HRM policies' implemented in their hotel. They only captured the policies when the researcher addressed recruitment, performance evaluation, and compensation examples. However, respondents realized that those policies are standard processes happening in their hotel. The first part of this research project has covered superiors and managers' perceptions of HRM practices. Findings have shown a good knowledge of HRM practices in their hotel. In the current study, as most respondents have the same understanding about HRM policies of their organization, this supports other researchers' arguments that the influence of co-worker's perception is more reliable than the manager's perception of HRM practices (Jiang et al., 2017). It is evidenced in the study that although their managers are well verse about HRM policies, however, it is different from their subordinates. Instead, employees share more understanding in general HRM practices with their coworkers compared to the managers. Based on the thematic analysis of the interviews' data and the assumption of AMO theory, the understanding of HRM policies and

Table 1

Background of the respondents

\begin{tabular}{|c|c|c|c|c|c|}
\hline & $\begin{array}{c}\text { Hotel } 1 \\
\text { (3 star) }\end{array}$ & $\begin{array}{c}\text { Hotel } 2 \\
\text { (2 star) }\end{array}$ & $\begin{array}{c}\text { Hotel } 3 \\
\text { (5 star) }\end{array}$ & $\begin{array}{c}\text { Hotel } 4 \\
\text { (5 star) }\end{array}$ & $\begin{array}{r}\text { Hotel } 5 \\
\text { (1 star) }\end{array}$ \\
\hline \multicolumn{6}{|l|}{ Gender } \\
\hline Male & 1 & & 5 & & 1 \\
\hline Female & 7 & 2 & 11 & 2 & 3 \\
\hline \multicolumn{6}{|l|}{ Age } \\
\hline $40-50$ & 1 & & 4 & & \\
\hline $30-39$ & 2 & & 9 & & 1 \\
\hline $20-29$ & 5 & 2 & 1 & 2 & 2 \\
\hline$<20$ & & & 2 & & 1 \\
\hline \multicolumn{6}{|l|}{ Ethnicity } \\
\hline Malay & 8 & 2 & 16 & 2 & 4 \\
\hline \multicolumn{6}{|l|}{$\begin{array}{l}\text { Education level } \\
\text { Bachelor }\end{array}$} \\
\hline Diploma & 2 & 1 & 1 & 1 & 1 \\
\hline Secondary school & 6 & 1 & 15 & 1 & 3 \\
\hline \multicolumn{6}{|l|}{ Department } \\
\hline Food \& beverages & & 1 & 10 & & 2 \\
\hline Admin & 6 & & 4 & & 1 \\
\hline Front Office & 2 & 1 & 2 & 2 & 1 \\
\hline Total & 8 & 2 & 16 & 2 & 4 \\
\hline
\end{tabular}


practices found in this study falls under all elements of ability, motivation, and opportunity. Specifically, recruitment and selection are categorized under Ability, performance management, and rewards under Motivation, and lastly, training practices fall under Opportunity.

Ability is related to recruitment and selection. Since the primary purpose of recruitment is to attract potential employees to join the company (Noe et al., 2014), this process requires identifying the most suitable person and fit with the job. The recruitment process ends with the selection when the company decides on whom to be employed. The decision will be made based on the criteria set by the management that suit the job descriptions, job specifications, and key members' expectations.

The motivation for employee desired behavior is influenced by two practices: performance management and rewards and benefits. The effective performance evaluation could ensure that employees realize the state of their performances and find ways to improve, where necessary. From rewards and compensation employees receive, the organization shows their appreciation of employees' contributions to the organizational achievement. These interpretations of HRM practices under the AMO domain are consistent with those reported in Guerci et al. (2017)'s study.

\section{Employees' Interpretations of HRM Practices}

Ability. Most respondents are aware of the recruitment method used by the hotel to recruit new employees. Respondents from Hotel 3 and 4 have a consensus on the recruitment method of their hotels. However, responses from the employees of other remaining hotels varied. Different employees reported different ways. For instance, in Hotel 1;

One respondent said,

I think this hotel usually informs the vacancy through social media like Facebook. For me, the social platform is suitable for now because most people referred to social media more than newspaper. (R1, H1)

Another respondent gave different feedback from the same hotel,

I know the vacancy at this hotel from the newspaper. It is easy to refer to newspaper because I am not always going online because I don't often have internet access at my place. (R2, H1)

Based on the interviews, respondents talked about different experiences they gained during the application process. It is similar to all hotels, except Hotel 1. Respondents of Hotel 1 agreed that they were recruited after their internship. The answer to the recruitment method from respondents of other hotels varied from a resume, application form, internship, and walk-in-interview. Respondents have agreed on the suitability of using social media for the recruitment process in recent times, albeit different experiences they gained in their time. 
For the selection process, respondents in all hotels have gone through the interview before working with the hotel. In terms of the content of the interview, consensus arrived at the understanding of general questions, such as academic background and work experiences. Interestingly, most respondents reported that they were not concerned much about the particular positions they came for the interview. It is encapsulated through the response;

I came for the interview with the entire certificates that I have and wear proper attire. I am not sure about the job, but I've heard about it from my friend. (R27, H4)

Others said;

My preparations before the interview are to make sure that I have brought all the documents needed and be on time. I have asked a few friends who have experience with job interviews, normally that is the first thing that the organization would ask from the candidates. So, I decided to take the advice because I don't have experience before. (R9, $\mathrm{H} 2$ )

Out of all respondents, only a minority of them were aware of the position they applied for because they have undergone the training of specific jobs. It is especially true for respondents who were selected after they finished their internship at the same hotel.

When discussing how they understand their job scope, respondents from Hotel
1,2 , and 3 believed they had been given the job description at the beginning of their employment period. For Hotel 4, mixed responses are reported from the interview. Those employees from the administration department said they have the job description, while employees from other departments have different opinions on that. They told the researcher that they had never been given the job description. However, respondents agreed that they did not refer to the job description to perform their job but mostly learned through observation and referred to their supervisors. For instance, one respondent spoke;

I don't know about others, but for myself, I just observe how the senior staff performs their job, and that guides me to perform mine. I think everybody is busy with their jobs, so it is easy to just look at how others did their job and do the same thing. I am afraid if you ask too many questions, it will disturb others to do their jobs. (R5, H1)

Similarly, other respondents said;

We don't refer to job description. We understand our job based on the explanation by the supervisor. Or else, I feel more comfortable discussing with my colleague if I have a problem performing my job. (R13, H3)

Employees' reliance on the supervisors and their colleagues suggests that the document prepared by the HR department 
failed as a guideline for the employees to perform their jobs. This situation could explain the gap in employee performance as they are not having a reliable source of information to understand their job expectations. Other researchers have highlighted the need for a clear and consistent policy to increase awareness among employees on the HRM-performance issue (Heffernan et al., 2016). Instead, in this study, more dependence on understanding job expectations is put into co-workers and supervisors. This finding is consistent with the study by Jiang et al. (2017), who found the influence of co-workers who shape more understanding of HRM practices. Unless the understanding of other co-workers is accurate, HRM practices may fail to foster better communication among employees to understand the expectation of their jobs (Cafferkey \& Dundon, 2015).

Motivation. Respondents claimed the existence of performance evaluation in their hotel but could not describe how the process is being implemented. Most of them perceived the feedback given by the supervisor during working time as part of the evaluation process. Respondents from Hotel 1 and 3 described the feedback during a morning briefing as a way of understanding the expectation of their job demands. This situation possibly causes the issue of employee performance in the hotel case study. While each employee has their way of defining the HRM practices implemented in their hotel, unfortunately, it is inconsistent with organization expectations.
For employees to be motivated, employees should own the universalistic understanding (Guest, 2011). It is to ensure the intended performance expected by the management is interpreted similarly by the employees. This situation also reflects the importance of supervisors or line managers to effectively communicate the HRM policies to the employees (Purcell et al., 2003). A different implementation of HRM policies between line managers may result in different understandings of the message received by employees.

Mixed responses were reported for the rewards and benefits. Respondents from three hotels (H1, H2, and H3) suggest that they are satisfied with their compensation. It has been described concerning the salary and other benefits provided by the hotel, including medical and food. Respondents from the remaining hotels spoke about their dissatisfaction because the salary given is not suitable for the skills and levels of education. Salary is another factor that influences the turnover (Luna-Arocas \& Camps, 2007): explains the situation in the hotel case study. Interestingly, respondents in all hotels disagreed about giving suggestions for improving the work process and their job scopes. It is encapsulated through the statements;

We never got the opportunity to speak up, especially to say our dissatisfaction. Sometimes my superior did ask about any suggestion, but it doesn't specifically focus on salary or rewards that we got. (R3, H1) 
I just follow the routine. I think if we give suggestions, it wouldn't be used anyway. Because at the end of the day, those who at the upper management who make the decision. We are not involved in that meeting. (R27, H4)

It could be a reflection of the nonexistence of organizational climate in the case study. The importance of the organizational climate is the organization's ability to nurture positive outcomes among employees (Ahmad \& Schroeder, 2003). As a result, employees are not motivated to perform more than their standard practice. While service quality is the primary concern for the hotel industry, this would be a signal that limits employee performance. Thus, the management needs to consider employee dissatisfaction, which would impact customers' satisfaction with the hotel service (Aminuddin, 2013).

\section{Opportunity to Perform. Consensus} arrived at the understanding that training is insufficient for employees. The only exception is respondents from Hotel 1, who believed the training was sufficient and assisted them in performing better. It is mainly related to the nature of the hotel as part of the training center for students who are interested in the hospitality industry. Thus, training is a typical program conducted by Hotel 1, unlike the other hotels.

Further, most respondents said their training is more general to the service quality program than specific to their particular jobs. Therefore, researchers suggested that HRM influences HRM activities rather than financial achievement (Purcell \& Kinnie, 2007). However, enhancing the employees' capabilities can be achieved through HRM activities like training and development (Nehles \& Veenendaal, 2017). Therefore, the failure to provide employees with the training to equip them with the necessary skills to perform their job may influence their satisfaction and performance at work. More importantly, training is also considered an appreciation to employees so that they realize the willingness of the hotel to invest in their development (Tremblay et al., 2010). Therefore, it is another possible explanation for the gap in employee performance in the hotel case study.

While each policy plays its part in transmitting the information to the employees to grasp their overall responsibilities when they hold a particular position, this suggests that employees' understandings need to cover all policies. These include policies aimed at attracting, developing, retaining, and motivating employees to assist the achievement of organizational goals. Thus, the implementation of HRM practices aims at assisting the employees to maximize their contribution to the organization. However, moving towards an innovation requires time and effort, which may not be possible in a short time without proper guidance and risk analysis. Therefore, employees are required to gain more ability to adapt to the current changes and job demands as expected by the organization (Sull et al., 2015). In turn, employees can 
contribute to organizational achievement and bridge their performance gap.

\section{CONCLUSION, LIMITATIONS OF THE STUDY, AND SUGGESTIONS}

This study examines the role of HRM policies and practices in enhancing employee work behavior that is significant to organizational achievement from the perspective of AMO theory. In this relationship, HRM practices represent the mechanisms that stimulate employees' work behavior that influence their performance. Based on the actual experience of employees with the implementation of HRM policies, it is proven that the gap between the expectations of top management and that of employees exists in the hotel case study. The crux of this performance gap is caused by the failure of HRM practices to transmit the right message of the employees' work expectations. Understanding work expectations is crucial as it will influence employees' work performance. In this study, all elements in the AMO theory are unable to be filled by HRM practices to assist employees to produce significant work behavior. This failure is interpreted through the weaknesses of these practices to provide the signal of employees' work requirements for them to perform and contribute to the organizational achievement. While the data for this study is limited to employees' experiences, more investigation from the perspectives of key-related parties involved in evaluating employees' performance would be beneficial to understanding the situation at the workplace. Investigating different levels of employees could provide insights into the acceptance and awareness of HRM policies and practices among employees. Regardless of the position and educational background, all employees must have sufficient knowledge of their work demands, especially in the context of the hospitality industry, where satisfied employees may largely influence customer satisfaction. Drawing on the assumptions of AMO theory, it is suggested that workplace development for innovation programs may be required to increase the effectiveness of the HRM implementation. It is to ensure that employees are prepared to adapt to the changes in their work demands. Furthermore, the role of line management is crucial to ensure the successful implementation of HRM policies and influence employees' behavior towards their jobs. Importantly, top management as an evaluator of employee performance should have an interest in, and nourish, a supportive HRM environment to open communication and participation towards engaging employees in the HRM activities to increase their understanding of the HRM processes. In turn, a better understanding of HRM policies and practices may potentially bridge the gap of employees' performance and contribute to the organization's development.

\section{IMPLICATIONS OF THE STUDY}

Theoretically, HRM issues are often viewed as context-dependent and interdependent (Cooke, 2017); thus, the current study is relevant to fill the HRM literature gap from International perspectives other than the 
Western world. Societal context (Malaysia as part of the non-western context) contributes to bridging the gap of HRM literature to reduce the dependency on Western values, which may not be compatible with other contexts (Parry et al., 2020). Further, employing qualitative research methodology contributes to overcoming the weaknesses of HRM research as proposed by researchers, particularly on the weak capability of the research data to explain the observed findings (Cascio, 2012; Chidlow et al., 2015; Romani et al., 2018). Using qualitative research design allows the explanation of 'how' and 'why' questions to explain the findings in more detail better (Yilmaz, 2013).

Practically, understanding employees' perceptions and behavior assist the organization to be prepared before dysfunctional behavior are produced by employees, which is detrimental for organizations, especially in the current situations where adaptability is a main requirement for organization to survive. While organizations are looking forwards for more effective and efficient operations especially in time of economic challenges and difficulties, an effort to bridge the performance gap is highly valuable not only to achieve the organizational target, but to reduce human errors that could cost more financial burden to the business. Moreover, as the nature of the hospitality industry lies with fluctuating customer demand and changing business goals over time, these require the hotel management to choose the most efficient approach in managing employees' performance, especially for Malaysia that applied tight cost-control practices in the hotel sector (Ahmad \& Scott, 2013; Mat et al., 2019).

\section{CO-AUTHOR CONTRIBUTIONS}

There is no conflict of interest during the completion of this article. All co-authors gave their commitment and contributed to the completion of this article.

\section{ACKNOWLEDGEMENT}

This research is supported by the Young Research Grant (68006/2016/67) from Universiti Malaysia Terengganu (UMT).

\section{REFERENCES}

Abdullah, R. B., Alias, M. A. M., Zahari, H., Karim, N. A., Abdullah, S. N., Salleh, H., \& Musa, M. F. (2010). The study of factors contributing to chef turnover in hotels in Klang Valley. Asian Social Science, 6(1), 80-85. https://doi.org/10.5539/ ass.v6n $1 \mathrm{p} 80$

Ahmad, S., \& Schroeder, R. G. (2003). The impact of human resource management practices on operational performance: Recognizing country and industry differences. Journal of Operations Management, 21(1), 19-43. https:// doi.org/10.1016/S0272-6963(02)00056-6

Ahmad, R., \& Scott, N. (2013). Managing the front office department: Staffing issues in Malaysian hotels. Anatolia, 25(1), 24-38. https://doi.org/1 $0.1080 / 13032917.2013 .822010$

Alfes, K., Shantz, A. D., Truss, C., \& Soane, E. C. (2013). The link between perceived human resource management practices, engagement, and employee behavior: A moderated mediation 
model. The International Journal of Human Resource Management, 24(2), 330-351. https:// doi.org/10.1080/09585192.2012.679950

Anderson, P. H., \& Kragh, H. (2010). Sense and sensibility: Two approaches for using existing theory in theory-building qualitative research. Industrial Marketing Management, 39(1), 49-55. https://doi.org/10.1016/j. indmarman.2009.02.008

Aminuddin, M. (2013). Human resource management in the hospitality industry. Oxford University Press.

Aryee, S., Walumbwa, F. O., Seidu, E. Y. M., \& Otaye, L. E. (2012). Impact of high-performance work systems on individual- and branch-level performance: Test of a multilevel model of intermediate linkages. Journal of Applied Psychology, 97(2), 287-300.

Baluch, A. M. (2017). Employee perceptions of HRM and well-being in nonprofit organizations: Unpacking the unintended. The International Journal of Human Resource Management, 28(14), 1912-1937. https://doi.org/10.1080/095 85192.2015 .1136672

Baran, M., Karabulut, E., Semercioz, F., \& Pekdemir, I. (2002). The new HR practices in changing organizations: An empirical study in Turkey. Journal of European Industrial Training, 26(2/3/4), 81-87. https://doi. org/10.1108/03090590210421950

Bos-Nehles, A. C., Riemsdjik, M. J. V., \& Looise, J. K. (2013). Employee perceptions of line management performance: Applying the AMO theory to explain the effect of line managers' HRM implementation. Human Resource Management, 52(6), 861-877. https://doi. org/10.1002/hrm.21578

Bowen, D. E., \& Ostroff, C. (2004). Understanding HRM-firm performance linkages: The role of the 'strength' of the HRM system. The Academy of Management Review, 29(2), 203-221. https://doi. org/10.2307/20159029

Boxall, P., \& Purcell, J. (2011). Strategy and human resource management (3rd ed.). Palgrave Macmillan.

Boxall, P., \& Steenveld, M. (1999). Human resource strategy and competitive advantage: A longitudinal study of engineering consultancies. Journal of Management Studies, 36(4), 444-463. https://doi.org/10.1111/1467-6486.00144

Budjanovcanin, A. (2018). Actions speak louder that action: How employees mind the implementation gap. The International Journal of Human Resource Management, 29(22), 3136-3155. https://doi.org/10.1080/09585192.2018.1443959

Buyens, D., \& Vos, A. D. (2001). Perceptions of the value of the HR function. Human Resource Management Journal, 11(3), 70-89. https://oi. org/10.1111/j.1748-8583.2001.tb00046.x

Buchanan, J., Scott, L., Yu, S., Schutz, H, \& Jakubauskas, M. (2010). Skills demand and utilisation: An international review of approaches to measurement and policy development (Working Papers, 2010/4). OECD Publishing.

Cafferkey, K., \& Dundon, T. (2015). Explaining the black box: HPWS and organizational performance. Personnel Review, 44(7), 666-688. https://doi.org/10.1108/PR-12-2012-0209

Cascio, W. F. (2012). Methodological issues in international HR management research. The International Journal of Human Resource Management, 23(12), 2532-2545. https://doi.or g/10.1080/09585192.2011.561242

Charlwood, A. (2015). The employee experience of high involvement management in Britain, in A. Felstead, D. Gallie, and F. Green (eds), Unequal Britain at work. Oxford University Press: Oxford. 
Chidlow, A. Ghauri, P. N., Yeniyurt S., \& Cavusgil, S. T. (2015). Establishing rigor in mail-survey procedures in international business research. Journal of World Business, 50, 26-35. https:// doi.org/10.1016/j.jwb.2014.01.004

Child, J., \& Marinova, S. (2014). The role of contextual combinations in the globalization of Chinese firms. Management and Organization Review, 10(3), 347-371.

Cooke, F. L. (2017). Concepts, contexts, and mindsets: Putting human resource management research in perspectives. Human Resource Management Journal, 28(1), 1-13. https://oi. org/10.1111/1748-8583.12163

Cunningham, I., \& Hyman, J. (1995). Transforming the HRM vision into reality: The role of line managers and supervisors in implementing change. Employee Relations, 17(8), 5-20.

De Jong, J. P. J., Parker, S. K., Wennekers, S., \& Wu, C. H. (2015). Entrepreneurial behavior in organizations: Does job design matter? Entrepreneurship Theory and Practice, 39(4), 981-995. https://doi.org/10.1111/etap.12084

Delaney, J. T., \& Huselid, M. A. (1996). The impact of human resource management practices on perceptions of organizational performance. The Academy of Management Journal, 39(4), 949969. https://doi.org/10.5465/256718

Delery, J. E., \& Shaw, J. D. (2001). The strategic management of people in work organizations: Review, synthesis, and extension. Research in Personnel and Human Resources Management, 20, 165-97. https://doi.org/10.1016/S07427301(01)20003-6

Den Hartog, D. N., Boon, C., Verburg, R. M., \& Croon, M. A. (2013). HRM, communication, satisfaction, and perceived performance: A cross-level test. Journal of Management, 39(6), 1637-1665. https://doi.org/10.1177/0149206312440118
Edwards, T., Marginson, P., \& Ferner, A. (2013). Multinational companies in cross-national context: Integration, differentiation, and the interactions between MNCs and nation states. Industrial and Labor Relations Review, 66(3), 547-587. https://doi. org/10.1177/001979391306600301

Epp, A. M., \& Otnes, C. C. (2021). High-quality qualitative research: Getting into gear. Journal of Service Research, 24(2), 163-167. https://doi. org/10.1177/1094670520961445

Fredrickson, B., \& Branigan, C. (2003). Positive emotions broaden the scope of attention and thought-action repertoires. Cognition and Emotion, 19(3), 313-332. http://doi. org/10.1080/02699930441000238

Gerhart, B. (2005). Human resources and business performance: Findings, unanswered questions, and an alternative approach. Management Review, 16(2), 174-86.

Gioia, D. A., Corley, K., \& Hamilton, A. L. (2013). Seeking qualitative rigor in inductive research: Notes on the Gioia methodology. Organizational Research Methods, 16(1), 15-31. https://doi. org/10.1177/1094428112452151

Guerci, M., Radaelli, G., De Battisti, F., \& Siletti, E. (2017). Empirical insights on the nature of synergies among HRM policies- An analysis of an ethics-oriented HRM system. Journal of Business Research, 71, 66-73. https://doi. org/10.1016/j.jbusres.2016.10.016

Guest, D. E. (2011). Human resource management and performance: Still searching for some answers, Human Resource Management Journal, 21(1), 3-13. https://doi.org/10.1111/j.17488583.2010.00164.x

Guest, D. E. (2017). Human resource management and employee wellbeing: Towards a new analytic framework. Human Resource Management Journal, 27(1), 22-38. https://doi. org/10.1111/1748-8583.12139 
Hall, L., \& Torrington, D. (1998). Letting go or holding on - The devolution of operational personnel activities. Human Resource Management Journal, 8(1), 41-55. https://doi. org/10.1111/j.1748-8583.1998.tb00158.x

Harney, B., \& Jordan, C. (2008). Unlocking the black box: Line managers and HRM-performance in a call centre context. International Journal of Productivity and Performance Management, 57(4), 275-296. https://doi. org/10.1108/17410400810867508

Heffernan, M., Harney, B., Cafferkey, K., \& Dundon, T. (2016). Exploring the HRM-performance relationship: The role of creativity climate and strategy. Employee Relations, 38(3), 438-462. https://doi.org/10.1108/17410400810867508

Horwath HTL. (2011). Horwath HTL 2011 Malaysia hotel operations survey results released. https:// www.hotelnewsresource.com/article57453.html.

Jack, G., Zhu, Y., Barney, J., Brannen, M. Y., Prichard, C., Singh, K., \& Whetten, D. (2013). Refining, reinforcing, and reimagining universal and indigenous theory development in international business. Journal of Management Inquiry, 22(2), 148-164. https:// doi.org/10.1177/1056492612458453

Jackson, S. E., \& Schuler, R. S. (1995). Understanding human resource management in the context of organizations and their environments. Annual Review of Psychology, 46, 237-264.

Jackson, S., Schuler, R., \& Jiang, K. (2014). An aspirational framework for strategic human resource management. Academy of Management Annals, 8(1), 1-56. https://doi.org/10.5465/1941 6520.2014 .872335

Jensen, J. M., Patel, P. C., \& Messermith, J. G. (2013). High-performance work systems and job control: Consequences for anxiety, role overload, and turnover intentions. Journal of Management, 39(6), 1699-1724. https://doi. org/10.1177/0149206311419663
Jiang, K., Lepak, D. P., Han, K., Hong, Y., Kim, A., \& Winkler, A. I. (2012). Clarifying the construct of the human resource management system: Relating human resource management to employee performance. Human Resource Management Review, 22(2), 73-85. https:/doi. org/10.1016/j.hrmr.2011.11.005

Jiang, K., Hu, J., Liu, S., \& Lepak, D. P. (2017). Understanding employees' perception of human resource practices: Effects of demographics dissimilarity to managers and co-workers. Human Resource Management, 56(1), 69-91. https://doi.org/10.1002/hrm.21771

Kaufman, B. (2015). Evolution of strategic HRM as seen through two founding books: A 30th anniversary perspective on development of the field. Human Resource Management, 54(3), 389407. https://doi.org/10.1002/hrm.21720

Kehoe, R. R., \& Wright, P. M. (2013). The impact of high-performance human resource practices on employees' attitudes and behaviors. Journal of Management, 39(2), 366-391. https://doi. org/10.1177/0149206310365901

Khilji, S. E., \& Wang, X. (2006). "Intended" and "implemented" HRM: The missing linchpin in strategic human resource management research. International Journal of Human Resource Management, 17(7), 1171-1189. https://doi. org/10.1080/09585190600756384

Luna-Arocas, R., \& Camps, J. (2007). A model of high performance work practices and turnover intentions. Personnel Review, 37(1), 26-46. https://doi.org/10.1108/00483480810839950

Malik, P., \& Lenka, U. (2019). Exploring the impact of perceived AMO framework on constructive and destructive deviance: Mediating role of employee engagement. International Journal of Manpower, 40(5), 994-1011. https://doi. org/10.1108/IJM-05-2018-0164

Mat, N. H. N., Yusof, Y., Salleh, H. S., \& Mohamed, W. N. (2017). Employees' understanding of 
HRM practices in the hotel industry. Advanced Science Letters, 23, 10680-10683. https://doi. org/10.1166/asl.2017.10129

Mat, N. H. N., Omar, K., Zabidi, Z. N., Yusof, Y., Salleh, H. S., Yusof, Y., Mohamed, W. N., \& Abdul Rani, I. N. F. (2019). Framework for managing the climate change impact in Malaysian hotel industry. Journal of Sustainability Science and Management, 14(3), 117-124.

Mayrhofer, W., Gooderham, P. N., \& Brewster, C. (2019). Context and HRM: Theory, evidence and proposals. International Studies of Management \& Organization, 49(4), 355-371. https://doi.org/ 10.1080/00208825.2019.1646486

McShane, S., \& Travaglione, T. (2007). Organizational behavior on the Pacific Rim (2nd ed.). McGrawHill.

Nadeem, S., \& Rahat, H. (2021). Examining the synergetic impact of ability-mitovationopportunity-enhancing high performance work practices. Human Performance, 34(3), 168-188. https://doi.org/10.1080/08959285.2021.1920021

Nehles, A. C., Riemsdijk, M. V., Kok, I., \& Looise, J. K. (2006). Implementing human resource management successfully: A first-line management challenge. Management Revue, 17(3), 256-273.

Nehles, A. C. B., \& Veenendal, A. A. R. (2017). Perceptions of HR practices and innovative work behavior: The moderating effect of an innovative climate. The International Journal of Human Resource Management, 30(18), 2661-2683. https://doi.org/10.1080/09585192. 2017.1380680 .

Noe, R. A., Hollenbeck, J. R., Gerhart, B., \& Wirght, P. M. (2014). Fundamentals of human resource management (5th ed.). McGraw-Hill.

Paauwe, J. (2009). HRM and performance: Achievements, methodological issues and prospects. Journal of Management Studies,
46(1), 129-142. https://doi.org/10.1111/j.14676486.2008.00809.x

Paauwe, J., \& Boselie, P. (2005). HRM and performance: What next? Human Resource Management Journal, 15(4), 68-83. https:/doi. org/10.1111/j.1748-8583.2005.tb00296.x

Parry, E., Farndale, E., Brewster, C., \& Morley, M J. (2020). Balancing rigour and relevance: The case for methodological pragmatism in conducting large-scale, multi-country and comparative management studies. British Journal of Management, 32(2), 273-282. https:// doi.org/10.1111/1467-8551.12405

Payne, J. (2012). Fronting up to skills utilisation: What can we learn from Scotland's skills utilisation projects? Policy Studies, 33(5), 419-438. https:// doi.org/10.1080/01442872.2012.709093

Purcell, J., \& Hutchinson, S. (2007). Front-line managers as agents in the HRM-performance causal chain: Theory, analysis and evidence. Human Resource Management Journal, 17(1), 3-20. https://doi.org/10.1111/j.17488583.2007.00022.x

Purcell, J., \& Kinnie, N. (2007). HRM and business performance. In P. Boxall, J. Purcell, \& P. Wright (Eds.), The Oxford handbook of human resource management. Oxford University Press.

Purcell, J., Kinnie, N., Hutchinson, S., Rayton, B., \& Swart, J. (2003). Understanding people and performance link: Unlocking the black box. Chartered Institute of Personnel and Development.

Romani, L., Barmeyer, C., Primecz, H., \& Pilhofer, K. (2018). Cross-cultural management studies: State of the field in the four research paradigms. International Studies of Management \& Organization, 48(3), 247-263. https://doi.org/1 $0.1080 / 00208825.2018 .1480918$

Nadeem, S. \& Rahat. H. (2021). Examining the synergetic impact of ability-motivation- 
opportunity-enhancing high performance work practices. Human Performance, 34(3), 168-188, https://doi.org/10.1080/08959285.2021.1920021

Sull, D., Homkes, R., \& Su, C. (2015). Why strategy execution unravels: And what to do about it. Harvard Business Review, 93(3), 57-66.

Syed, J., Mingers, J., \& Murray, P. A. (2009). Beyond rigour and relevance: A critical realist approach to business education. Management Learning, 41(1), 71-85. https:// doi.org/10.1177/1350507609350839

Szulc, J. M., Davies, J., Tomzcak, M. T., \& McGregor, F. L. (2021). AMO perspectives on the well-being of neurodivergent human capital. Employee Relations, 43(4), 858-872. https://doi. org/10.1108/ER-09-2020-0446

Tremblay, M., Cloutier, J., Simard, G., Chenevert, D., \& Vandenberghe, C. (2010). The role of HRM practices, procedural justice, organizational support and trust in organizational commitment and in-role and extra-role performance. International Journal of Human Resource
Management, 21(3), 405-433. https://doi. org/10.1080/09585190903549056

Wright, T. (2003). Positive organizational behavior: An idea whose time has truly come. Journal of Organizational Behavior, 24(4), 437-442. https:// doi.org/10.1002/job.197

Wright, P., \& Nishii, L. (2013). Strategic HRM and organizational behavior: Integrating multiple levels of analysis. In J. Paauwe, D. Guest, \& P. Wright (Eds.), HRM and performance: Achievements and challenges (pp. 97-110). Wiley-Blackwell.

Yilmaz, K. (2013). Comparison of quantitative and qualitative research tradition: Epistemology, theoretical and methodological differences. European Journal of Education, 48(2), 311-325. https://doi.org/10.1111/ejed.12014

Yuan, F., \& Woodman, R. W. (2010). Innovative behavior in the workplace: The role of performance and image outcome expectations. Academy of Management Journal, 53(2), 323342. https://doi.org/10.5465/amj.2010.49388995 
